\title{
Peningkatan Ekonomi Keluarga Melalui Pemanfaatan Tanaman Toga Sebagai Jamu Keluarga
}

\author{
Siti Lestari ${ }^{1 *}$, Fenny Roshayanti ${ }^{2}$, Veryliana Purnamasari ${ }^{3}$
}

1,2,3 Universitas PGRI Semarang

\section{A R T I C L E I N F O}

Article history:

Received 20 December 2018

Received in revised form 1 January 2019

Accepted 30 January 2019

Available online 27

February 2019

\section{Kata Kunci:}

budidaya tanaman toga dan produk limbah jamu.

Keywords:

cultivation of toga plants and herbal waste products

\begin{abstract}
A B S T R A K
Fokus program kegiatan adalah peningkatan penghasilan anggota Keluarga Mitra melalui program unggulan budidaya tanaman toga sebagai jamu kelurga. Pembentukan kluster dalam program kegiatan ini, meliputi: (1). Kluster budidaya tanaman toga sebagai bahan baku jamu, dan (2). Kluster diversifikasi produk dari limbah jamu. Kluster ini terdiri atas dosen, mahasiswa, pemerintah kabupaten, dan masyarakat / mitra kerja yang bekerja secara sinergis dan terpadu untuk menghasilkan budidaya tanaman toga dan olahan limbah jamu. Penjaminan berkelanjutan program dilakukan melalui pengembangan kerjasama dengan berbagai elemen masyarakat, akademisi, stake holder, dan industri. Pelaksanaan program didasarkan pada riset yang telah dilakukan oleh dosen, instansi terkait, dan mahasiswa TIM KKNPPM Universitas PGRI Semarang yang terdiri atas berbagai disiplin ilmu. Hasil dari kegiatan KKN PPM ini adalah tersedianya bahan baku melalui budidaya tanaman toga di Kelurahan Wonolopo, diversifikasi produk dari limbah jamu berupa sabun rempah dan pupuk organik cair, dan pemasaran secara online produk jamu dan olahan dari limbah jamu. Kegiatan ini dapat menambah penghasilan masyarakat Kelurahan Wonolopo dan menciptakan 2 UMKM baru yaitu UMKM Sabun Rempah dan UMKM Pupuk Organik Cair yang berbahan baku limbah jamu.
\end{abstract}

A B S T R A C T

Focus programs are outline and systematic in order to solve problems and ways of community empowerment can take place continuously. The focus of the activity program is to increase the income of members of the mitra through a superior program of toga plant cultivation as a family herbal medicine. The formation of clusters in this program of activities includes: (1). Cluster of toga plant cultivation as raw material for herbal medicine, and (2). Product diversification cluster from herbal waste. This cluster consists of lecturers, students, district governments, and communities / work partners who work synergistically and integrated to produce toga plant cultivation and processed herbal waste. Continuous guarantee programs are carried out through the development of cooperation with various elements of society, academics, stakeholders, and industry. The implementation of the program is based on research that has been carried out by lecturers, relevant agencies, and students of the KKN PPM team consisting of various scientific disciplines. The results of the KKN PPM activities are the availability of raw materials through toga plant cultivation in Wonolopo Village, product diversification from herbal waste in the form of spices soap and liquid organic fertilizer, and online marketing of herbal products and processed from herbal waste. This activity can increase the income of the Wonolopo Village community and create 2 new "UMKM", namely "UMKM Sabun Rempah" and "UMKM Pupuk Organik Cair" made from herbal waste.

Copyright $($ C Universitas Pendidikan Ganesha. All rights reserved.

\footnotetext{
* Corresponding author.

E-mail addresses: sitilestari@gmail.com (Siti Lestari)
} 


\section{Pendahuluan}

Kelurahan Wonolopo merupakan salah satu wilayah Negara Republik Indonesia yang terletak di Kecamatan Mijen, Kota Semarang, Provinsi Jawa Tengah dengan luas wilayah $403.800 \mathrm{Ha} / \mathrm{m} 2$. Tanah di Kelurahan Wonolopo tergolong tanah yang subur dengan didukung oleh pengaturan irigasi yang baik. Daya tarik yang ditawarkan desa wisata ini adalah homestay, wisata outbond, dan wisata tanam padi dengan menikmati jamu tradisional.

Potensi Perekonomian di Kelurahan Wonolopo menurut Rupabumi Wilayah Administrasi DesaKelurahan Kota Semarang Tahun 2012, berupa: (1). Pertanian, (2). Peternakan (seperti kambing, sapi dan unggas), (3). Home Industri. Mata pencarian penduduk Kelurahan Wonolopo sebagian besar sebagai petani dan pembuat jamu. Pemanfaatan tanah oleh masyarakat Kelurahan Wonolopo adalah tanah pertanian dan peternakan.

Sebagian besar pembuat jamu di Kelurahan Wonolopo masih membeli bahan baku di pasar sehingga keuntungan para penjual jamu tergolong kecil. Dari segi pengolahan limbah sisa jamu pun masih dibuang, belum termanfaatkan. Menurut Survey Subdit Aneka Tanaman (2001), jumlah kebutuhan tanaman toga dalam negeri adalah $36.200 \mathrm{~kg} / \mathrm{bulan}$. Untuk kebutuhan lokal, demand komoditas tanaman obat tradisional yang meningkat seiring dengan semakin banyaknya pabrik jamu, farmasi, dan kosmetik banyak dimanfaatkan sebagai bahan baku obat tradisional (jamu), bahan makanan, minuman dan kosmetika. Oleh karena itu, budidaya tanaman toga sangat dibutuhkan.

Selain kebutuhan tanaman toga sebagai bahan baku jamu, Kelurahan Wonolopo saat ini juga tengah merintis kampung jamu. Oleh karena itu, kebutuhan akan bahan baku jamu ini terus meningkat sebagai komoditas yang mendukung pariwisata di Kota Semarang.

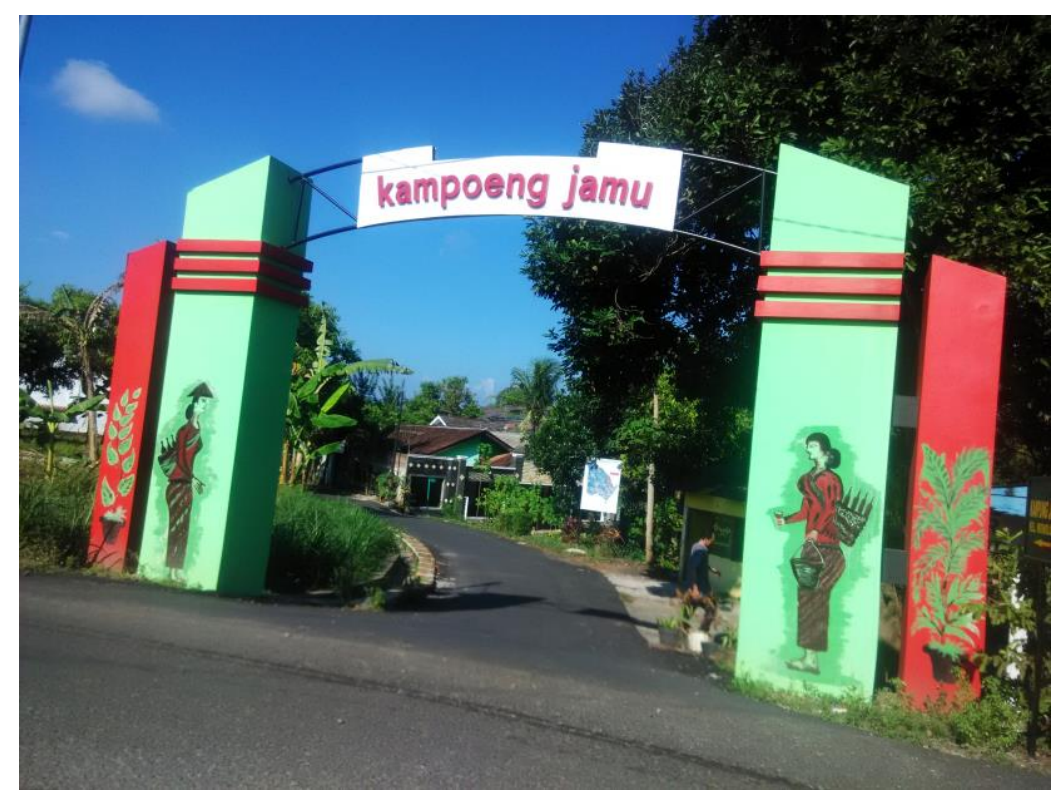

Gambar 1. Gapura Kampung Jamu Wonolopo

Berangkat dari kondisi di atas, Universitas PGRI Semarang memprogramkan KKN PPM di Kelurahan Wonolopo, Kecamatan Mijen, Kota Semarang. Program tersebut menitikberatkan pada budidaya tanaman toga sebagai bahan baku jamu yang dapat digunakan sebagai jamu keluarga. Dengan demikian dapat meningkatkan taraf perekonomian warga di Kelurahan Wonolopo.

Dari hasil diskusi yang dilakukan antara LPPM Universitas PGRI Semarang, Badan Pemberdayaan Masyarakat Desa sebagai penanggung jawab, Badan Perencanaan Pembangunan Daerah, Kepala Desa, pelaku UKM disepakati pelaksanaan KKN-PPM Universitas PGRI Semarang mengacu pada Peraturan dengan menggarap secara bersama-sama dengan pemberian keterampilan yang berbasis pertanian dengan memperhatikan potensi masyarakat, kondisi daerah, yaitu budidaya tanaman toga dan pengolahan limbah jamu.

Adapun beberapa vokasi yang dipersiapkan di Kelurahan Wonolopo, yaitu (a).Vokasi berbasis pertanian budidaya tanaman toga, (b).Vokasi berbasis industri rumah tangga berupa olahan limbah jamu. Kedua vokasi itu akan dipersiapkan dengan sasaran yang berbeda. Vokasi berbasis industri rumah tangga dipersiapkan untuk sasaran ibu-ibu rumah tangga, dan vokasi yang berbasis pertanian tanaman toga 
dipersiapkan untuk semua penduduk. Vokasi atau keterampilan unggulan yang dipilih berdasarkan diskusi antara Kelompok Mitra, tokoh masyarakat, LPPM Universitas PGRI Semarang, Badan Pemberdayaan Masyarakat dan Desa Kota Semarang, Badan Perencanaan Pembangunan Daerah Kota Semarang, dan masyarakat Kelurahan Wonolopo adalah budidaya tanaman toga.

Menurut Survey Subdit Aneka Tanaman (2001), jumlah kebutuhan tanaman toga dalam negeri adalah $36.200 \mathrm{~kg} /$ bulan. Untuk kebutuhan lokal, demand komoditas tanaman obat tradisional yang meningkat seiring dengan semakin banyaknya pabrik jamu, farmasi, dan kosmetik banyak dimanfaatkan sebagai bahan baku obat tradisional (jamu), bahan makanan, minuman dan kosmetika. Oleh karena itu, budidaya tanaman toga mempunyai peluang yang besar untuk meningkatkan perekonomian masyarakat

\section{Metode}

Metode yang dilakukan antara lain persiapan dan pembekalan, pelaksanaan program KKN PPM dan tindaklanjut program KKN PPM. Untuk mencapai hasil yang optimal dilakukan beberapa kegiatan yang berkaitan dengan mekanisme pelaksanaan kegiatan KKN-PPM, sebagai berikut: (1). Pengumpulan Data, (2). Identifikasi Masalah, (3). Formulasi Kegiatan, (4). Implementasi Kegiatan, dan (5). Evaluasi Akhir. Sedangkan materi persiapan dan pembekalan KKN-PPM yang diberikan kepada mahasiswa antara lain pengetahuan tentang budidaya tanaman toga, pengetahuan tentang olahan limbah jamu, pengetahuan tentang pengembangan produk, pemasaran dan membangun jaringan, dan pengetahuan sosialisasi dengan masyarakat.

Pada tahap pelaksanaan, untuk mengefektifkan pembinaan dan pendampingan digunakan metode / cara pembentukan kluster sesuai dengan bidang binaan. Dalam program KKN-PPM kali ini membentuk 2 kluster bidang binaan yang sesuai dengan tema / topik KKN-PPM. Kedua kluster binaan itu sebagai berikut: (1) kluster produksi meliputi sosialisasi dan penyuluhan kepada warga binaan tentang teknik budidaya tanaman toga, pengolahan limbah jamu, pelatihan budidaya tanaman toga, pengolahan limbah jamu, pendampingan pengurusan legalisasi perizinan, diskusi dan pertemuan mingguan yang membahas masalah-masalah yang timbul dan evaluasi produk, bahan baku, dan manajemen. (2) kluster pemasaran/marketing yang terdiri dari sosialisasi dan penyuluhan tentang pengetahuan pemasaran, pelatihan pemasaran.. launching produk, pendampingan pemasaran, menentukan target capaian dan wilayah pemasaran dan distribusi produk ke pangsa pasar.

Rencana keberlanjutan program ini melalui pendampingan pemilihan bibit tanaman toga, pengolahan limbah jamu, pendampingan jaringan pemasaran limbah jamu, pendampingan dalam legalisasi ijin usaha

\section{Hasil dan pembahasan}

Berdasarkan pada program kerja dan target tim KKN-PPM hingga saat ini, keseluruhan program dapat terlaksana. Ketercapaian tersebut dapat dilihat pada uraian laporan hasil yang dicapai sebagai berikut. Pelaksanaan Program KKN-PPM Universitas PGRI Semarang memiliki beberapa program yaitu: (1) Memberikan alternatif penyelesaian yang nyata bagi pemberdayaan masyarakat Kelurahan Wonolopo dengan meningkatkan penghasilan mereka. Pemilik UKM penghasilan bertambah $20 \%$ - 50\%, dan anggota binaan pengahsilannya meningkat dari tidak punya penghasilan tambahan menjadi mempunyai penghasilan.(2) Meningkatkan lapangan kerja bagi bagi ibu PKK di Kelurahan Wonolopo dengan produksi sabun sebagai hasil diversifikasi produk dari limbah jamu (3) Meningkat kemitraan yang sinergis antara Perguruan Tinggi, Pemerintah Kota Semarang dan masyarakat Jawa tengah secara umum.

Sebagai upaya untuk mengefektifkan pembinaan dan pendampingan digunakan metode/cara pembentukan kluster sesuai dengan bidang binaan sebagaimana yang telah dirancang pada tahap sebelumnya. Dalam program KKN-PPM yang direncanakan 2 kluster dibentuk menjadi 3 kluster adalah; (1) Kluster budidaya tanaman toga, (2) Kluster diversifikasi produk dari limbah jamu (3) Kluster pemasaran produk jamu dan produk dari limbah jamu.

Secara rinci pelaksanaan masing-masing kluster tersebut adalah sebagai berikut: pada kluster budidaya tanaman toga dengan kegiatan sosialisasi dan penyuluhan tentang teknik budidaya tanaman toga, pelatihan pembibitan tanaman toga, pendampingan proses budi daya, pemantauan proses budidaya tanaman toga, pendampingan pembuatan pembukuan dan manajemen, diskusi dan pertemuan mingguan yang membahas masalah-masalah yang timbul, evaluasi produk, bahan baku, dan manajemen

Dari program-program yang ada pada kluster produksi sampai saat ini Tim KKN-PPM telah melaksanakan sosialisasi dan penyuluhan tentang teknik budi daya tanaman toga. Tim KKN-PPM telah melakukan koordinasi dengan Badan Pemberdayaan Masyarakat Desa, Rapat koordinasi dengan Kepala Desa. Perangkat Desa, Rapat koordinasi dengan pelaku UKM dan ketua kelompok keluarga mitra, 
Mempersiapkan materi sosialisasi, kebutuhan teknis yang menunjang sosialisasi dan penyuluhan, Menyusun acara dan agenda sosialisasi dan penyuluhan, Pelaksanaan sosialisasi dan penyuluhan yang meliputi; sosialisasi dan penyuluhan tentang teknik budidaya tanaman toga, sosialisasi dan penyuluhan tentang pembibitan tanaman toga dan perawatannya dan sosialisasi dan penyuluhan manajemen.

Pendampingan proses pengolahan produk utama dan diversifikasi produk. Rapat koordinasi dengan Lurah dan perangkatnya, pelaku UKM dan keluargamitra, Mempersiapkan peralatan, bahan baku, kebutuhan teknis yang menunjang pelatihan, Mengumpulkan ketua kelompok dan anggota kelompok mitra, Pelaksanaan pelatihan tentang budidaya tanaman toga.

Monitoring dan pendampingan proses budidaya tanaman toga, telah dilakukan melalui beberapa kegiatan, yaitu menjalin koordinasi dengan Lurah dan perangkatnya, pelaku UKM, dan fasilitator, Survei secara berkala terhadap proses produksi ke anggota warga kelompok mitra binaan, Pencatatan hasil monitoring secara berkala, Diskusi membahas hasil monitoring secara berkala tentang kasus-kasus yang dijumpai dalam monitoring. Program akhir dari kluster produksi ini berupa evaluasi budidaya tanaman toga belum mulai dilaksanakan karena budidaya tanaman toga ini masih berjalan pada tahap pengelolaan dan pembibitan. Dapat dilaporkan dari kluster produksi program telah terlaksana.

Dalam kluster diversifikasi produk dari limbah jamu kegiatan yang telah dilakukan antara lain sosialisasi dan penyuluhan tentang diversifikasi produk dari limbah jamu, pelatihan diversifikasi produk dari limbah jamu, pendampingan diversifikasi produk dari limbah jamu, pemantauan proses diversifikasi produk dari limbah jamu, pendampingan pembuatan pembukuan dan manajemen, diskusi dan pertemuan mingguan yang membahas masalah-masalah yang timbul, evaluasi produk, bahan baku, dan manajemen

Dari program-program yang ada pada kluster diversifikasi produk dari limbah jamu sampai saat ini Tim KKN-PPM telah melaksanakan sosialisasi dan penyuluhan tentang diversifikasi produk dari limbah jamu. Tim KKN-PPM telah melakukan koordinasi dengan Badan Pemberdayaan Masyarakat Desa, Rapat koordinasi dengan Kepala Desa. Perangkat Desa, Rapat koordinasi dengan pelaku UKM dan ketua kelompok keluarga mitra, Mempersiapkan materi sosialisasi, kebutuhan teknis yang menunjang sosialisasi dan penyuluhan, Menyusun acara dan agenda sosialisasi dan penyuluhan, Pelaksanaan sosialisasi dan penyuluhan yang meliputi; sosialisasi dan penyuluhan tentang diversifikasi produk dari limbah jamu, sosialisasi dan penyuluhan tentang diversifikasi produk dari limbah jamu dan perawatannya dan sosialisasi dan penyuluhan manajemen.

Pendampingan proses pengolahan produk utama dan diversifikasi produk melalui rapat koordinasi dengan Lurah dan perangkatnya, pelaku UKM dan keluargamitra, Mempersiapkan peralatan, bahan baku, kebutuhan teknis yang menunjang pelatihan, Mengumpulkan ketua kelompok dan anggota kelompok mitra, Pelaksanaan pelatihan tentang diversifikasi produk dari limbah jamu.

Monitoring dan pendampingan proses diversifikasi produk dari limbah jamu, telah dilakukan melalui beberapa kegiatan, yaitu; menjalin koordinasi dengan Lurah dan perangkatnya, pelaku UKM, dan fasilitator, Survei secara berkala terhadap proses produksi ke anggota warga kelompok mitra binaan, Pencatatan hasil monitoring secara berkala, Diskusi membahas hasil monitoring secara berkala tentang kasus-kasus yang dijumpai dalam monitoring, program akhir dari kluster produksi ini berupa evaluasi diversifikasi produk dari limbah jamu belum mulai dilaksanakan karena proses diversifikasi produk dari limbah jamu ini masih berjalan pada tahap pembuatan produk. Dapat dilaporkan dari kluster produksi program telah terlaksana..

Pada kluster pemasaran/marketing, kegiatan yang telah dilakukan antara lain sosialisasi dan penyuluhan tentang pengetahuan pemasaran kepada kelompok jamu dan kelompok diversifikasi limbah jamu, pelatihan pemasaran, launching produk, pendampingan pemasaran, membangun jaringan pemasaran dengan cara bekerja sama dengan toko, warung, melatih melakukan pembukuan keuangan, pendampingan pengerjaan pembukuan, menentukan target capaian dan wilayah pemasaran, distribusi produk ke pangsa pasar, evaluasi pemasaran

Berdasarkan program-program dalam kluster ini, Tim KKN-PPM telah melaksanakan programprogram tersebut dengan melakukan pengelompokan kegiatan sebagai berikut sosialisasi penyuluhan tentang pengetahuan pemasaran produk jamu dan produk dari limbah jamu melalui rapat koordinasi dengan dinas perindustrian dan perdagangan, kepala desa untuk menyusun program sosialisasi dan penyuluhan, Mempersiapkan materi dan kebutuhan teknis yang menunjang sosialisasi dan penyuluhan, Pelaksanaan sosialisasi dan penyuluhan tentang jamu dan produk dari limbah jamu; a. Strategi meningkatkan nilai jual jamu dan produk dari limbah jamu, b. Peningkatan pangsa pasar jamu dan produk dari limbah jamu.Pendampingan pemasaran dengan enentukan target capaian dan wilayah pemasaran dan embangun jaringan pemasaran Pelatihan pembukuan dan manajemen dengan mempersiapkan materi pelatihan, kebutuhan, teknik yang menunjang pelatihan pembukuan dan manajemen, Pelatihan pembukuan dan manajemen kepada petugas pemasaran, Pendampingan pembukuan dan manajemen, 
Sebagai tahap akhir dari kluster pemasaran/marketing ini adalah evaluasi dan berbagai analisis hasil dari program pemasaran yang belum dilaksanakan karena program yang menjadi tahapan sebelumnya masih berlangsung, namun dapat disampaikan bahwa kemajuan pelaksanaan program KKNPPM keseluruhan program yang direncanakan telah terlaksana.

Berdasarkan uraian beberapa program yang telah terlaksana tersebut dapat dilaporkan bahwa proses pelaksanaan program KKN-PPM ini telah mencapai 100\% dari program keseluruhan yang menjadi rancangan awal. Hasil dari kegiatan KKN PPM ini adalah tersedianya bahan baku melalui budidaya tanaman toga di Kelurahan Wonolopo, diversifikasi produk dari limbah jamu berupa sabun rempah dan pupuk organik cair, dan pemasaran secara online produk jamu dan olahan dari limbah jamu. Kegiatan ini dapat menambah penghasilan masyarakat Kelurahan Wonolopo dan menciptakan 2 UMKM baru yaitu UMKM Sabun Rempah dan UMKM Pupuk Organik Cair yang berbahan baku limbah jamu

\section{Simpulan dan saran}

Berdasarkan uraian yang telah disampaikan pada laporan kemajuan pelaksanaan program KKNPPM ini, dapat disimpulkan bahwa pelaksanaan program KKN-PPM yang mencapai $100 \%$ dari total program yang direncanakan telah terlaksana dengan baik dan sesuai target. Hasil dari kegiatan KKN PPM ini adalah tersedianya bahan baku melalui budidaya tanaman toga di Kelurahan Wonolopo, diversifikasi produk dari limbah jamu berupa sabun rempah dan pupuk organik cair, dan pemasaran secara online produk jamu dan olahan dari limbah jamu. Kegiatan ini dapat menambah penghasilan masyarakat Kelurahan Wonolopo dan menciptakan 2 UMKM baru yaitu UMKM Sabun Rempah dan UMKM Pupuk Organik Cair yang berbahan baku limbah jamu.

Program KKN-PPM Universitas PGRI Semarang tahun 2018 ini menjadi sarana bagi mahasiswa sebagai tempat pembelajaran nuntuk mengaplikasikan dan mengembangkan ilmu pengetahuan yang dipelajari di bangku kuliah dan di lingkungan masyarakat, melatih kemampuan berpikir kritis, menganalisis masalah secara cermat, dan mencari solusi terbaik dalam menghadapi berbagai persoalan yang berhubungan dengan bidang keilmuan secara teoritis dan praktis. Mahasiswa juga memperoleh kesempatan mempelajari ilmu-ilmu interdisipliner yang dapat dipadukan dalam penyelesaian masalah secara nyata dan dapat diaplikasikan langsung dalam lingkungan masyarakat.

Disamping itu program KKN-PPM juga mampu menumbuhkan rasa kepedulian, empati, serta kepekaan sosial terhadap kondisi permasalahan di masyarakat miskin (ekonomi lemah) sehingga dapat membangun kesadaran dan perubahan perilaku dan sikap mahasiswa yang diwujudkan dalam upaya pemberdayaan masyarakat sesuai dengan bidang keilmuan dan kondisi yang sebenarnya

\section{Daftar Rujukan}

Anonimous. 2013. Qualitative traits and Quantitaive traits in animals.http://web2.mendelu.cz/af_291_projekty2/vseo/stranka.php?kod=471.

Diakses 2 Desember 2014.

Bappeda Provinsi Jawa Tengah, publikasi Jawa Tengah Dalam Angka 2014, diakses tanggal 24 Maret 2015 jam 15.30 WIB

Marwati, Tri. 2013. Teknologi Pascapanen Tanaman Obat. Balai Besar Penelitian dan Pengembangan Pascapanen Pertanian. Bogor

Tangkeallo, C., dan Widyaningsih, T. D., 2014. Aktivitas Antioksidan Serbuk Minuman Instan Berbasis Miana Kajian Jenis Bahan Baku dan Penambahan serbuk Jahe. Jurnal Pangan dan Agroindustri Vol.2 No.4.

Wijayakusuma, Hembing. 2000. Potensi Tumbuhan Obat Asli Indonesia Sebagai Produk Kesehatan. Risalah Pertemuan Ilmiah Penelitian dan Pengembangan Teknologi Isotop dan Radiasi.. 